\title{
As Listas Negras e a Grande Guerra: Repercussões sobre Capital e Trabalho Germânicos em Porto Alegre
}

Stefan Chamorro Bonow ${ }^{*}$

Resumo: O presente artigo pretende salientar alguns dos efeitos provocados pela Primeira Guerra Mundial na economia da capital gaúcha. Desde o primeiro momento, a conflagração acarretou efeitos diversos sobre a economia brasileira. Como decorrência do bloqueio oceânico efetuado pela Grã-Bretanha contra a Alemanha, ocorreram alterações na balança comercial e na arrecadação. No caso gaúcho, elas foram bem nítidas. Houve, também, repercussões direta e especificamente relacionadas à etnia alemã; estas, menos conhecidas. Porto Alegre era, à época, o principal centro industrial do estado e, para isto, foi importante a presença da imigração de origem germânica, tanto entre os capitalistas quanto entre os operários da cidade. Quando as Listas Negras foram aplicadas a partir de 1915 como arma de guerra, os indivíduos de etnia germânica passaram a ser, internamente, alvo de maior desconfiança. São esses os fatos que se pretende destacar aqui.

Palavras-chave: Primeira Guerra Mundial, alemães, Porto Alegre.

Abstract: This article aims to highlight some of the effects raised by the First World War in the economy of Rio Grande do Sul (RS) capital. Since the first moment, the conflagration caused several effects on the Brazilian economy. As a result of the blockade ocean made by Great Britain against Germany, changes in the Trade balance and in the collection occurred. In the case of RS state, they were very clear. There were also direct impacts and they were specifically related to German's ethnic group; these less well known. Porto Alegre was, at the time, the main industrial center of the state and, for this, the presence of German immigration origin was important, as well as among capitalists and the city workers. When blacklists were implemented as a war weapon from 1915 on, ethnic German people became internally target of further distrust. These are the facts that we want to highlight here.

Keywords: First World War, germans, Porto Alegre.

Para muitas pessoas, quando se fala que a comunidade germânica foi submetida a restrições no Brasil - tanto naquilo que diz respeito às liberdades individuais quanto às econômicas - em decorrência da guerra, é comum pensar que se está falando de reminiscências da década de 1940. Dificilmente, alguém negará que foi provocado um mal-estar por causa da Segunda Guerra Mundial. Terá, certamente, alguém que trará, do fundo de suas lembranças, algum episódio relacionado a si, ou a um parente, ou a um vizinho, que sofreu em virtude do nome, da compleição física, talvez por causa do sotaque; e, soturnamente, dirá que foram tempos difíceis. Certamente, o Estado Novo impregnou as recordações das pessoas com suas proposições nacionalistas. Contudo, poucos trazem consigo alguma informação (em

* Bolsista CAPES e doutorando em História do PPG-PUCRS. 
parte, porque a maior distância temporal ajuda a ceifar a memória) sobre qualquer dos eventos de poucas décadas anteriores a isso.

Seria interessante tratar dos motivos pelos quais persiste um certo esquecimento sobre os infortúnios causados à comunidade germânica durante os anos da década de 1910. Embora a quantidade de pessoas atingidas pelas restrições, durante a Segunda Guerra Mundial, possivelmente seja de maior monta, não foram estas as únicas a terem sofrido os dissabores da discriminação, em seus diferentes matizes. Por certo, faz-se necessário um maior número de pesquisas para explicar o motivo da pouca expressão que a Primeira Guerra Mundial ${ }^{1}$ exerce, a ponto de um renomado jornalista ter afirmado, por ocasião da sua dissertação em Relações Internacionais ${ }^{2}$, que não houve nenhum tipo de perseguição nesse período.

Apesar da importância de explicar o motivo dessa lacuna, infelizmente, o presente espaço não permite maiores digressões. A necessária objetividade impõe que a questão seja relegada a uma outra oportunidade.

No momento, o artigo estará cumprindo um papel satisfatório ao registrar que, durante a Primeira Guerra Mundial (ou, como se dizia à sua época, a Grande Guerra), uma série de sanções tolheu qualquer suspeito de entabular relações com empresas e indivíduos considerados alemães, o que incluiu muitos membros da etnia germânica. No que tange à cidade de Porto Alegre (centro econômico do Rio Grande do Sul e uma das cidades mais industrializadas do país), interessa tratar de uma sanção econômica específica. No caso, vinculada aos habitantes germânicos ${ }^{3}$ (aqui definidos como sendo tanto os alemães quanto os teuto-brasileiros) da cidade, que eram maioria entre aqueles que foram prejudicados.

\footnotetext{
${ }^{1}$ No Brasil, o trabalho mais importante foi realizado por VINHOSA, Francisco L. Teixeira. O Brasil e a Primeira Guerra Mundial. 1 ed., Rio de Janeiro: Instituto Histórico e Geográfico Brasileiro, 1990. Na obra, o autor faz um apanhado geral das repercussões da guerra no Brasil e a atuação do país enquanto beligerante, ao declarar guerra à Alemanha, no final de 1917. Há também um trabalho publicado nos Estados Unidos, sobre as repercussões do conflito na vida dos alemães que viviam no sul do Brasil, ver: LUEBKE, Frederick C. Germans in Brazil: A comparative History of Cultural conflict during World War I. First edition, Louisiana: Louisiana State University Press, 1987. Há ainda um trabalho feito na Inglaterra, no qual aborda os efeitos econômicos da guerra sobre os países da América do Sul, entre os quais o Brasil, ver: ALBERT, Bill. South America and the first world war: the impact of the war on Brazil, Argentina, Peru and Chile. First paperback edition, Cambridge: Cambridge Press, 2002.

${ }^{2}$ GARAMBONE, Sidney. A Primeira Guerra Mundial e a Imprensa Brasileira. 1ạ ed., Rio de Janeiro: Mauad, 2003, p. 107.

${ }^{3}$ Os alemães seriam aqueles que nasceram na Alemanha e que por algum motivo migraram para o Brasil. Os teuto-brasileiros, descendentes daqueles que, em diferentes períodos vieram para o Brasil, anterior ou posteriormente a 1870. Essa denominação alcança maior expressão no Rio Grande do Sul com a militância política de Karl von Koseritz (tendo ele mesmo sido imigrante). Enquanto representante na Assembleia Legislativa Provincial, ele defendia que os imigrantes se nacionalizassem brasileiros, integrarem-se ao país, sem perder suas características culturais. Sobre a atuação política dele, ver: MOTTER, Ana Elisete. As relações entre as bancadas teuta e luso-brasileira na Assembleia Legis/tativa Provincial Rio-Grandense (1881-1889). São Leopoldo: Unisinos, 1999. Dissertação (Mestrado), Faculdade de História, Universidade do Vale do Rio dos Sinos, 1999.
} 
Em 1915 (portanto, no ano posterior ao do começo das hostilidades), o governo britânico lançou mão de uma medida polêmica, que veio a acarretar constrangimentos ao Ministério das Relações Exteriores do Brasil. Foi posta em prática a Statutory List, vulgarmente conhecida como Lista Negra (ou Black List). Em virtude dela, os súditos britânicos ficavam proibidos de estabelecer relações econômicas com qualquer indivíduo ou empresa que tivesse origem em qualquer dos países inimigos - mesmo que estivessem em países neutros. Para a fiscalização, tiveram papel relevante os consulados britânicos espalhados pelo mundo, pois os agentes consulares deveriam listar os nomes dos desobedientes, para entregar ao Foreign Office de Sua Majestade. Acontece que, as investidas desses cônsules no Brasil extrapolaram os limites usuais de suas atribuições e redundaram em pressão sobre as empresas brasileiras. Uma vez que negociar com alguém da lista ocasionava a entrada na mesma, estava estabelecido o problema. Intimações, exigências e denúncias, feitas de modo a desrespeitar sistematicamente a soberania brasileira, se repetiram continuamente. De diferentes estados do Brasil chegavam queixas relatando as pressões sofridas.

Em 1916, uma correspondência bem esclarecedora, entre os ministérios de ambos Estados, dava o tom dramático da situação. Nela, o Brasil alertava para que houvesse comedimento e, a seguir, citava um caso relacionado a uma sociedade que seria criada em Manaus a partir da fusão de vinte e uma empresas, mas que havia sido vetada pelo cônsul britânico local. Entre outras questões, o gabinete da representação brasileira apelava:

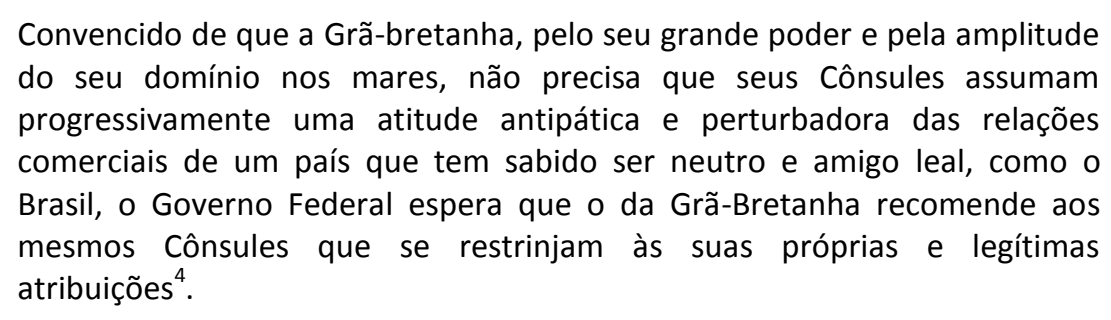

Em resposta, a legação britânica enviou uma nota na qual se comprometia a averiguar possíveis abusos de poder, requisitava uma lista de cada caso, mas que, no de Manaus, a legação britânica julgava procedente a ação de seu cônsul. No final, mostrando conhecimento da situação econômica do nosso país, e do desenvolvimento que negociantes de origem alemã tinham em terras sul-americanas. Com uma dose de malícia, mostrava-se surpreso com o tom lastimoso vindo do Brasil ao afirmar:

V. Ex. deixa ao mesmo tempo de aludir às imensas vantagens que tantas firmas brasileiras auferem, presentemente, da mesma política que as

${ }^{4}$ Guerra da Europa - Documentos Diplomáticos - Atitudes do Brasil: 1914-1918. 1 ed., Rio de Janeiro: Imprensa Nacional, p. 119. 
habilitou a desenvolver vários ramos do comércio que estavam anteriormente quase que exclusivamente em poder de interesses alemães ${ }^{5}$.

Cerca de quinhentas firmas brasileiras chegaram a ser citadas nas listas ${ }^{6}$. 0 embaraço se tornou maior devido ao fato da legislação brasileira vigente não exigir que fosse registrada a origem dos fundos aplicados no país ${ }^{7}$. O quiproquó em questão serviu para mostrar que os princípios liberais que haviam servido de referencial para economia brasileira, oriundos da própria Grã-Bretanha, no momento não vinham ao caso, maculando a tradicional fleuma e os princípios da livre concorrência que sempre foram defendidos pelos britânicos, como base da civilização (na qual os alemães, digase de passagem, de acordo com boa parte da bibliografia produzida na época, não se enquadravam).

Com relação à última afirmação, parece adequado fazer certas digressões, que talvez sejam pertinentes. Por certo, elas acabam por se afastar do escopo da discussão, e, em virtude disto, exigem brevidade, embora não seja um fator que as eximam de crítica. Contudo, elas se tornam necessárias para prestar amparo ao comentário realizado sobre o liberalismo britânico.

Quando a guerra irrompeu, poucas mentes supunham que a duração da mesma se estenderia para além de alguns poucos meses, o otimismo imperava em ambos os lados do conflito, portanto, os países não estavam adequadamente preparados para um esforço de grande fôlego ${ }^{8}$. Uma vez que os números dos combatentes envolvidos giravam na casa dos milhões, os esforços para manter as máquinas de guerra eram igualmente hercúleos. Para neutralizar ou minorar a efetividade da força de combate do inimigo, também seriam necessárias grandes medidas de exceção. Por decorrência das circunstâncias de guerra, tornam-se, assim, compreensíveis determinadas atitudes (contemporizáveis), de modo que não se julgue com tamanho rigor comportamentos que, em circunstâncias amenas seriam tomados simplesmente por draconianos. As excepcionalidades que envolvem uma guerra se encarregam de facultar certa compreensão aos boicotes econômicos realizados pelos Estados, mesmo os de índole liberal e concorrencial, como foi o caso da coação britânica às relações comerciais brasileiras e o bloqueio das rotas de comércio e navegação da Alemanha.

\footnotetext{
${ }^{5}$ Idem, p. 121.

${ }^{6}$ ALBERT, op. cit.

${ }^{7}$ FAUSTO, Boris (dir.). História Geral da Civilização Brasileira: estrutura de poder e economia (1889-1930). 8a ed., Rio de Janeiro: Bertand Brasil, 2006.

${ }^{8}$ TUCHMAN, Bárbara. Canhões de Agosto. Tradução de Eliana Sabino. 1ạ ed., Rio de Janeiro: Biblioteca do Exército Editora, 1998.
} 
Reprovável seria tomar com rigor apenas um dos inimigos. É sabido que o tempo e a opinião de muitos condenaram a Alemanha por atitudes que, já com anterioridade, foram qualificadas como repudiáveis pelo conjunto das nações, mas acusações também pesaram contra a Grã-Bretanha. O deputado brasileiro Dunshee de Abranches ${ }^{9}$, germanófilo declarado, alertara quanto ao comportamento dissimulado de Albion. Ele denunciara que a declaração de guerra submarina total, efetivada pelos alemães no início de 1917, foi uma retaliação ao uso de bandeiras de países neutros pelos navios britânicos em águas internacionais, bem como à colocação de armas em navios mercantes. Esses artifícios também eram considerados proibidos pelos acordos internacionais.

No final das contas, guerra é guerra. Contudo, o comportamento britânico, no quase meio século que antecedeu a 1914, desvanece a noção de serena conviç̧ão dos britânicos quanto ao livre mercado.

Como decorrência da crise do final do século XIX, a agricultura deles foi deixada à própria sorte para garantir a entrada de alimentos a preços competitivos, mas houve protestos à entrada na Inglaterra de outros produtos europeus ${ }^{10}$. Além do que, guardadas as sutis variáveis que facultaram o imperialismo do período, as quais não há como abordar no momento, se deve ressaltar uma análise feita por Acosta Sanchez, que via nos imperialismos britânico e francês um sinal da debilidade de ambos em se adaptar à Segunda Revolução Industrial e manter uma capacidade de concorrência na indústria e no comércio frente à Alemanha e aos Estados Unidos ${ }^{11}$. Por certo o capital financeiro deles permaneceu avassalador e aberto ao mercado, inegável na sua pujança, mas se beneficiando da fragilidade de outros segmentos internos que não transpareciam a mesma segurança. Contudo, mesmo assim, não impediu intimidações a outros Estados soberanos para assegurar o retorno dos investimentos, como ocorreu em relação à Venezuela, desde o final do século XIX, e em relação ao Brasil, nos procedimentos que antecederam o estabelecimento do Funding-Loan. Ao que parece, também a Grã-Bretanha esteve premida em uma luta interna de duas tendências, sujeita a manifestar ambas as lógicas, a capitalista e a territorialista, no sentido que atribui Giovani Arrighi ${ }^{12}$. Portanto, desde a década de 1870 ela não manifestava,

\footnotetext{
${ }^{9}$ ABRANCHES, Dunshee. A Ilusão Brasileira. 2a ed., Rio de Janeiro: Imprensa Nacional, 1917.

${ }^{10}$ LANDES, David. Prometeu desacorrentado: transformação tecnológica e desenvolvimento industrial na Europa ocidental, desde 1750 até os dias de hoje. Tradução de Marisa Rocha Motta. 1ạ ed., Rio de Janeiro: Elsevier, 2005.

${ }^{11}$ ACOSTA Sánchez, José. El imperialismo capitalista. 1aㅡ ed., Barcelona: Blume, 1977

${ }^{12}$ ARRIGHI, Giovanni. O longo século XX. Tradução de Vera Ribeiro. 5a ed., Rio de Janeiro: Contraponto; São Paulo: Editora UNESP, 2006.
} 
internamente, consenso e conviçcão para se agarrar na mão invisível que a conduziria novamente à rota das águas tranquilas da economia.

É interessante observar como as recorrentes ações britânicas, nesse quase meio século que antecedeu a guerra, não vieram a dar contornos definitivos a um histórico marcado pelo dístico da desconfiança, similar ao da Alemanha, por exemplo. Ponderado isso, seria adequado voltar ao assunto central do texto.

Sem embargo o constrangimento a que eram as empresas submetidas em decorrência da vigilante atuação dos aliados, há de se destacar a diligente atuação do governo brasileiro. Em suas denúncias contra a falta de tato no agir para com as empresas sediadas no Brasil, geralmente, se conseguia fazer com que os nomes fossem retirados das listas ${ }^{13}$.

A ruptura das relações entre o Brasil e a Alemanha e a posterior declaração de guerra a esta última, em outubro de 1917, se deveram à sucessão de naufrágios de embarcações brasileiras. No dia 31 de janeiro de 1917, a legação brasileira em Berlim recebeu a notificação de que o Reich alemão passaria a exercer um bloqueio marítimo irrestrito em determinadas coordenadas do Atlântico Norte e que não se responsabilizaria pelos navios que entrassem na área de patrulha - o que não foi bem aceito pelo governo brasileiro.

Seis dias após o infeliz naufrágio do navio mercante Paraná, em 11 de abril, o Brasil rompia relações com a Alemanha. Nesse ínterim, houve comícios, passeatas e atentados aos estabelecimentos de origem germânica em Porto Alegre. As janelas do jornal $O$ Diário - abertamente germanófilo - foram apedrejadas junto com as lâmpadas, sendo que, em seguida, o prédio do periódico teve a placa com seu nome e a bandeira brasileira arrancadas. A placa nunca mais foi colocada, nem o jornal voltou a funcionar ${ }^{14}$. O Hotel Schmidt, cujo proprietário alvejou a tiros uma multidão que passava à frente do estabelecimento foi incendiado. Em seguida dezenas de outros estabelecimentos foram alvos da fúria, entre os quais estava a firma Bromberg \& Cia., de importação e exportação, que, além da sua sede própria, era acionista de outras empresas - também alvejadas.

A destruição causada ao comércio da comunidade germânica foi tão contundente que no quarto distrito da cidade, núcleo habitacional do operariado (muitos da já referida origem) e sede de vários estabelecimentos comerciais, as

\footnotetext{
${ }^{13}$ BUENO, Clodoaldo. Política Externa da Primeira República: os anos de apogeu - de 1902 a 1918. 1a ed., São Paulo: Paz e Terra, 2003.

${ }^{14}$ SILVA JR., Adhemar Lourenço. O Povo X Der Pöbel. In: MAUCH, Cláudia. Os alemães no sul do Brasil. 1a ed., Canoas: Ulbra, 2004.
} 
depredações vararam muitas casas. Nesses locais, na maioria, os estragos foram de pequena monta, restringindo-se a vidros despedaçados.

Outros três naufrágios de navios brasileiros ocorreram até outubro desse ano, deteriorando mais as relações entre ambos, chegando ao limite no dia vinte e cinco de outubro. A partir desse momento, o Brasil se encontraria em guerra com o império alemão.

Quando da declaração de guerra, a situação ligada à lista se atenuou, pois passou a ser do próprio interesse do país exercer maior fiscalização sobre possíveis irregularidades comerciais em tempo de conflagração, como afirmara o Ministro das Relações Exteriores, Nilo Peçanha. ${ }^{15}$

A Lista Negra pode ser observada como sendo um recurso a mais, a serviço da guerra moderna, na qual o esforço pela vitória é mais eloquente, grandioso, já que a mobilização de tropas passa a ser medida por milhões de soldados, a produção industrial se adequa às necessidades do Estado em conflito e a vida dos civis se molda pela vida daqueles que lutam nos campos de batalha. Todavia, a mesma também se mostrou sintomática do recuo nas relações comerciais britânicas.

No ano de 1912, os Estados Unidos já destacavam-se como os principais consumidores das mercadorias brasileiras, seguidos da Alemanha e, em terceiro, pela Grã-Bretanha. Quanto às exportações, os britânicos ainda eram os primeiros (com alguma folga), seguidos pelos alemães e norte-americanos, embora, ao longo do século $\mathrm{XX}$, a taxa de crescimento britânica se desse em níveis baixos e a dos outros dois fosse bastante auspiciosa ${ }^{16}$.

As dificuldades encontradas pela Grã-Bretanha já vinham de anos anteriores. A pressão a que foi submetida, principalmente a partir do último quartel do XIX, provou ser bastante desgastante; dentro da Europa, principalmente com a Alemanha.

Acontece que a indústria alemã vinha em ritmo acelerado. Chamava a atenção, e suas demandas requeriam um planejamento especial, uma vez que a capacidade produtiva superava os prognósticos. Se até o final da década de 1880 podia-se especular sobre o futuro alemão, a partir da seguinte todas as estimativas positivas haviam se concretizado. Para se ter uma ideia, entre 1890 e 1913, as exportações do país triplicaram, e a marinha se afirmara como a segunda maior do mundo ${ }^{17}$. No mesmo período, a população alemã era superior à francesa em mais de vinte e sete milhões de habitantes, e superior, em cerca de vinte e um milhões, à da Grã-

\footnotetext{
${ }^{15}$ Guerra da Europa, op. cit., p. 183.

${ }^{16}$ BUENO, op. cit.

${ }^{17}$ KENNEDY, Paul. Ascensão e queda das grandes potências: transformação econômica e conflito militar de 1500 a 2000. Tradução de Waltensir Dutra. 1a ed., Rio de Janeiro: Campus, 1989.
} 
Bretanha ${ }^{18}$. As exportações foram consequências da indústria que também se elevou. Além do mais, a produção de ferro e carvão alemã superara a britânica ${ }^{19}$. Tanto a produção de ferro quanto a produção de aço, pela Alemanha, eram duas vezes maiores que a britânica ${ }^{20}$. No seu conjunto, os números culminaram com a liderança germânica no continente europeu.

Para uma percepção mais acurada da mudança em andamento, a marinha mercante alemã passou, de 640 mil toneladas, em 1870, para 5 milhões, em $1914^{21}$. Aproximadamente, 70\% das negociações alemãs passaram a ocorrer por mar e, entre 1890 e 1913, as exportações alemãs triplicaram ${ }^{22}$.

O poder naval alemão era uma clara ameaça ao predomínio britânico. Da perspectiva dos analistas geopolíticos britânicos, os ganhos alemães eram secundários diante das possibilidades territoriais de um império da extensão da Alemanha, enquanto a manutenção do controle de rotas comerciais era absolutamente vital para um pequeno arquipélago como a Grã-Bretanha ${ }^{23}$. Assim, as pretensões alemãs eram vistas como risco iminente.

Por outro lado, o Estado que mais cresceu e aumentou sua participação no comércio mundial, entre 1870 e 1913, foi o norte-americano. No começo do século XX, os Estados Unidos da América já ocupavam o primeiro lugar no mercado mundial, seguido da Grã-Bretanha e da Alemanha. Em 1913, ocorreu a troca de lugar entre o segundo e o terceiro. O mesmo pode ser aplicado às relações com o Brasil ${ }^{24}$. Contudo, há duas questões importantes a serem consideradas. A primeira diz respeito ao contexto histórico, pois, à época, as decisões importantes sobre os problemas mundiais eram ainda tomadas no velho continente, e o equilíbrio de poder mundial era uma extensão em maior escala do equilíbrio de poder europeu. A segunda se refere ao fato da orientação diplomática alemã após a saída de Bismarck (que sempre se propôs a evitar que a Alemanha pudesse causar sobressaltos aos britânicos). No governo do Kaiser Guilherme II (com sua Weltpolitik), as pretensões territoriais alemãs passaram a perturbar os interesses da Grã-Bretanha, o que a tornava cada vez mais apreensiva com relação à Alemanha.

\footnotetext{
${ }^{18}$ Idem.

${ }^{19}$ MAURO, Fredéric. História Econômica Mundial (1790-1970). Tradução de Lincoln Penna. 2ª ed., Rio de Janeiro: Zahar, 1976.

${ }^{20}$ LANDES, op. cit.

${ }^{21}$ MAURO, op. cit., p. 274.

${ }^{22}$ KENNEDY, op. cit.

${ }^{23}$ HOBSBAWM, Eric. A era dos extremos. Tradução de Sieni Maria Campos e Yolanda Steidel de Toledo. 3a ed., Rio de Janeiro: Paz e Terra, 1988.

${ }^{24}$ BUENO, op. cit.
} 
No que dizia respeito ao Brasil, é importante tomar em consideração que a participação alemã na economia do país deve ser observada enquanto resultado de uma conjuntura de abrangência mundial e cuja intensidade cresceu a partir do reinado de Guilherme II. Externamente, foi, em parte, um reflexo do desgaste ao qual a GrãBretanha estava submetida com o crescimento da concorrência durante a segunda fase da Revolução Industrial, e em parte, reflexo da capacidade alemã de repensar a economia capitalista durante a crise do final do século XIX.

Durante o período de Bismarck, a Alemanha se inclinava a reconhecer uma maior ascendência norte-americana sobre o conjunto do continente americano. Em realidade, o próprio não via com bons olhos a emigração de alemães ${ }^{25}$. Com a entrada de Caprivi, na chancelaria alemã em substituição a Bismarck, houve uma mudança no enfoque. Buscar-se-ia evitar entrar em choque com os Estados Unidos, mas visando uma maior aproximação em relação aos emigrados da América do Sul, estreitando os laços culturais e econômicos. Na América do Norte, os emigrantes estariam se deixando absorver pela ascendência cultural britânica ${ }^{26}$. Com uma nova perspectiva de futuro, a existência de laços culturais anteriores se tornara um argumento na expansão de novos mercados para a Alemanha, principalmente na América do Sul.

Por certo havia indivíduos na Alemanha que chegaram a desejar um domínio formal, ou a criação de colônias oficiais em locais onde havia forte presença da imigração germânica, mas até onde se têm informações, ideias nesse sentido não possuíam maior ressonância junto ao governo a ponto de uma ofensiva alemã sobre o Brasil poder realmente ser encarada como risco concreto ${ }^{27}$. Interessava, em essência, obter maior clientela nessas regiões. Porém, Isabel Arendt ${ }^{28}$ mostra as relações entre uma dessas organizações alemãs - a Alldeutscher Verband (Liga Pangermanista) -, dada a arroubos expansionistas, com outras desenvolvidas no Rio Grande do Sul. Tais entidades eram normalmente ligadas à educação de famílias imigrantes e, além da defesa da cultura germânica, militavam a favor do estreitamento de laços comerciais entre imigrantes e a Heimat (terra natal).

Em realidade, o comércio com a América do Sul significou uma interessante fonte de negócios para a Alemanha. Afinal, até antes da primeira guerra, "os países

\footnotetext{
${ }^{25}$ CUNHA, Jorge Luiz da. Conflitos de interesses sobre a colonização alemã do Brasil na segunda metade do século XIX. Estudos Ibero-americanos, Porto Alegre, v. 26, n. 1, p. 183-233, 2000.

${ }^{26}$ CUNHA, op. cit.

${ }^{27}$ René. O perigo alemão. 1ạ ed., Porto Alegre: Ed. da Universidade / UFRGS, 1991.

${ }^{28}$ ARENDT, Isabel Cristina. Representações de germanidade, escola e professor no Allgemeine Lehrerzeitung für Rio grande do Sul (Jornal Geral para o Professor no Rio Grande do Sul). São Leopoldo: Unisinos, 2005. Tese (Doutorado) Faculdade de História, Universidade do Vale do Rio dos Sinos, 2005.
} 
sul-americanos eram os maiores consumidores do comércio alemão"29. Mesmo que, durante décadas, o chanceler de ferro houvesse pensado que nenhuma possível influência valesse arriscar as boas relações da Alemanha com os norte-americanos ${ }^{30}$.

Mantendo o tato nas pretensões sobre o Brasil, a Alemanha obteve lucros, principalmente através do comércio de material bélico com o governo brasileiro. Negócios de grande envergadura, que envolviam concessões governamentais, evidenciaram a confiança de um país no outro (além da possibilidade de grandes cifras), bem como, despertaram inveja nas potências rivais.

A presença alemã na economia brasileira não possuía a mesma abrangência da britânica, mas era importante. Os alemães injetaram capital no país. Entre os últimos dez anos do século XIX e os primeiros do XX, foram inauguradas seis companhias de seguros. O capital entrou, posteriormente, inserido na indústria, na agricultura e no comércio, para tanto buscou se afirmar através de laços de afinidade com elementos políticos brasileiros; no caso do Rio de janeiro, chegara a conseguir o arrendamento do cais do porto ${ }^{31}$.

No estado de São Paulo a penetração alemã fora mais profunda do que no Rio. Agiu atentando a própria possibilidade de repercussão negativa entre os brasileiros, quanto à penetração dos estrangeiros. Iniciativa que partiu do próprio império alemão, uma vez que

o deputado Delbrück, do Reichstag alemão, apresenta um projeto conhecido por seu nome, onde se estipula que, [...] deve-se nacionalizar a economia internacional alemã, isto é, as firmas no estrangeiro devem associar-se a pessoas proeminentes do lugar ${ }^{32}$.

Era uma medida precavida no intuito de resguardar os interesses do país em caso de conflito futuro. Assim, algumas companhias cujo capital era majoritariamente alemão, procuravam associar-se a brasileiros. A política foi de fato introduzida, sendo que, pode-se apontar que,

em 1912, a Companhia de Indústrias Têxteis, alemã, com fábricas em São Paulo, Salto e Rio de Janeiro, aceita como sócios os srs. Carlos de Campos, Altino Arantes, Bernardino de Campos etc. Em 1916, os proprietários

\footnotetext{
${ }^{29}$ FUNKE, Alfred (org.). O Brasil e a Alemanha (1822-1922). 1a ed., Berlim: Editora Internacional, 1923.

${ }^{30}$ MAGALHÃES, Marionilde Brepohl de. Pangermanismo e nazismo: a trajetória alemã rumo ao Brasil. Campinas: Unicamp, 1998.

${ }^{31}$ CARONE, Edgard. A primeira república (1889-1930): instituições e classes sociais. 2a ed., São Paulo: Difusão Européia do Livro, 1970.

${ }^{32}$ CARONE, op. cit., p. 139.
} 
alemães da C. I. T. aceitam novos sócios brasileiros, numa outra fábrica de tecidos em Itatiba $^{33}$.

Durante o início do século $\mathrm{XX}$, o café permaneceu com os preços aquém do esperado pelos produtores e não conseguia alcançar o patamar obtido uma década atrás. O plano de valorização do produto no estado de São Paulo foi iniciado com a tomada, no ano de 1906, de um empréstimo no valor de um milhão de libras, tomado junto ao banco alemão Deutsche Discont Gesellschaft ${ }^{34}$.

Um fato em particular provocou, aqui no Brasil, uma antipatia muito grande em relação à Alemanha. Após criticar os subterfúgios dos exportadores de café qque lucravam às custas dos produtores nacionais), São Paulo buscou a ajuda dos mesmos na consecução do plano de valorização de café (outros estados produtores também viriam a seguir o exemplo). Para tanto, foi formado um consórcio de norte-americanos, franceses e alemães; liderado pelo alemão Hermann Sielcken ${ }^{35}$. Na transação dos direitos, a casa comercial do também alemão Theodor Wille, que comprava café em nome de três estados brasileiros: São Paulo, Rio de Janeiro e Minas Gerais, recebeu o monopólio sobre os estoques da Europa e dos Estados Unidos como garantia do empréstimo feito aos estados de São Paulo, Rio de Janeiro e Minas Gerais. Apesar da contestação dos governos dos Estados Unidos e da França, o esquema deu certo, mas por causa de ameaças do primeiro, o consórcio se desfez em 1913. Uma parte dos investidores do consórcio permaneceu vinculada ao Brasil, para orientar a inserção do café que ainda estava estocado no mercado. Quando os estoques foram vendidos, o dinheiro acabou depositado em um banco na Alemanha, para ser em seguida transferido ao Brasil. O problema maior se deu quando, tendo iniciado a guerra de 1914, o dinheiro acabou confiscado pelo governo alemão. O dinheiro ficou retido na casa bancária Bleischroeder, em Berlim, pois a Alemanha temia que o dinheiro viesse a cair nas mãos da Inglaterra, cujos investidores teriam direito a parcela ${ }^{36}$. Esse incidente, nos anos seguintes, deu origem ao litígio entre os dois países, arbitrado durante as negociações do pós-guerra.

Outro elemento interessante está circunscrito à questão dos armamentos. A relevância desse fato certamente teve influência sobre o pensamento dos responsáveis do governo brasileiro pela modernização das forças armadas. Quando, em 1904, o Congresso aprovou a reorganização da esquadra, os estaleiros

\footnotetext{
${ }^{33}$ Idem.

${ }^{34}$ TOPIK, Steven. A Presença do Estado na Economia Política do Brasil de 1889 a 1930. 1a ed., Rio de Janeiro: Record, 1987, p. 83.

${ }^{35}$ FAUSTO, op. cit.

${ }^{36}$ BUENO, op. cit.
} 
contemplados para a encomenda brasileira foram os da inglesa Vickers - que resultou nas modernas embarcações São Paulo, Minas Gerais e Rio de Janeiro -, porque a Inglaterra era a senhora dos mares, todavia a blindagem dos mesmos ficou a cargo da alemã Krupp. Obra no valor de dois milhões de libras ${ }^{37}$. Em se tratando dos demais equipamentos militares, todos foram encomendados na Alemanha ${ }^{38}$. O Barão do Rio Branco, homem forte da chancelaria brasileira, atilado quanto às questões vinculadas ao poder dos Estados, reconhecia a relação entre indústria e poderio militar, bem como a relevância da Alemanha ${ }^{39}$. No nível das relações exteriores, a aproximação comercial entre o governo brasileiro e as empresas alemãs deixava as outras potências europeias desgostosas.

Outra parte do resultado pode ser observada através das relações comerciais estabelecidas com o estado do Rio Grande do Sul. Até a primeira metade do século XIX, nesse estado destacara-se o poderio dos pecuaristas. Além de terem no charque um produto responsável pela existência de grandes fortunas, eram esses os senhores que pautavam as importações. No período, as importações não tinham um montante muito elevado em proporção com a população, mas eram principalmente oriundas da Inglaterra. Ela "fornecia 1/3 das nossas compras, vindo pela ordem, logo após, cidades Hanseáticas, Estados Unidos, Repúblicas do Prata, Portugal, Espanha, França, Itália, Suécia, Noruega, Bélgica, além de outros países com pequenas proporções" ${ }^{40}$.

Posteriormente, com o estabelecimento da república, muita coisa acabou alterada. Os pecuaristas perderam muito da sua glória e do seu poder. A Inglaterra também deixou de ser o principal exportador para o estado, substituído pela Alemanha. Para isso contribuiu o estabelecimento de linhas de navegação a vapor entre os dois pontos. Até o estabelecimento de um canal de comunicação direto do sul do Brasil com a Europa, os comerciantes ficavam à mercê do Rio de Janeiro, onde se encontravam as linhas de transporte. No quartel final do século XIX, estava à disposição o Norddeutscher Lloyd, da cidade de Bremen, bem como a Hamburg Südamerikanische Dampfschiffahrtsgesellschaft, da cidade de mesmo nome; ambas eram alemãs. A partir da década de 1880 , o número de navios provenientes de Hamburgo superava os de Liverpool ${ }^{41}$.

\footnotetext{
${ }^{37}$ BANDEIRA, Luiz Alberto Muniz. Brasil, Argentina e Estados Unidos: conflito e integração na América do Sul (Da Tríplice Aliança ao Mercosul 1870-2003). 2a ed., Rio de Janeiro: Revan, 2003.

${ }^{38}$ Era uma grande quantidade, resultado de um plano de modernização. Incluía 50 mil fuzis e 10 mil carabinas, entre outros petrechos. Ver: BANDEIRA, op. cit.

${ }^{39}$ HAYES, Robert. A nação armada: a mística militar brasileira. 1ạ ed., Rio de Janeiro: Biblioteca do Exército Editora, 1991.

${ }^{40}$ SILVA, Elmar. Ligações externas da economia gaúcha (1736-1890). In: DACANAL, José Hildebrando; GONZAGA, Sergius (orgs.). RS: Economia e Política. 1 ed., Porto alegre: Mercado Aberto, 1979, p. 71.

${ }^{41}$ ROCHE, Jean. A colonização alemã e o Rio Grande do Sul. 1a ed., Porto Alegre: Globo, 1969.
} 
Em Porto Alegre, tal alteração foi bem recebida. Para uma ideia mais clara, basta ver que na cidade, na passagem da década de 1880 para a década de 1890, o número de estabelecimentos comerciais que possuíam nome alemão praticamente havia dobrado, chegando a quarenta e uma casas. As de origem inglesa, francesa e italiana, no mesmo período, juntas, chegavam a quatro. Em 1914, o número de casas germânicas já era de noventa e seis, contra treze, somando juntas as de origem inglesa, francesa e italiana ${ }^{42}$.

Dinheiro oriundo da Alemanha havia pouco. Um banco alemão foi aberto, apenas em 1904. "Era a sucursal porto-alegrense da Brasilianische Bank für Deutschland, fundado em 1887, em Hamburgo" ${ }^{43}$ e que já tinha agências em outras partes do Brasil há mais tempo. Todavia, apesar do pouco investimento alemão, os comerciantes de origem tiveram papel decisivo para o desenvolvimento do sistema bancário de Porto Alegre. Antes da Primeira Guerra, além de contribuírem para a fundação e administração do Banco da Província, já no longínquo ano de 1858, foram acionistas e administradores do Banco do Comércio (1895) e do Porto Alegrense $(1906)^{44}$.

A liderança incontestável do capital controlado por casas comerciais de importação e exportação capitaneadas por alemães e descendentes foi transposta para a indústria. A importação e o comércio de máquinas, graças à abundante acumulação de capital, deram oportunidade à formação de uma rede industrial ${ }^{45}$.

Na região colonial, onde estavam fixados os pontos de conexão com a cidade de Porto Alegre, acontecia um processo semelhante com a abertura de fábricas, cujo capital era oriundo do comércio. Todavia, foi Porto Alegre o local cujo capital provindo desse setor foi aplicado na indústria de modo mais contundente. A banha deu início à atividade fabril, através de Edmundo Dreher, Hugo Bins e Alfredo Dillenburg, que passaram a refinar o produto. No setor de fiação e vestuário, se inseriram os comerciantes Oscar Teichmann, Félix Kessler e Frederico Bier. No ramo metalmecânico, foi impressionante a participação teuta, onde se destacam nomes como os de Alberto Bins, Emmerich Berta, Johan Gerdau, Pedro Wallig, Armando Martau, entre outros $^{46}$. De acordo com Joseph Love ${ }^{47}$, para o volume total da produção do estado,

\footnotetext{
${ }^{42}$ Idem.

${ }^{43}$ Idem, p. 450.

${ }^{44}$ Idem, p. 452.

${ }^{45}$ LAUTERT, Vladimir. A dinâmica da concentração geográfica da indústria no Rio Grande do Sul: 1872 a 2000. Ensaios FEE, Porto Alegre, v. 26, Número Especial, p. 37-62, 2005.

${ }^{46}$ PESAVENTO, Sandra Jatahy. De como os alemães tornaram-se gaúchos pelos caminhos da modernização. In: MAUCH, Cláudia. Os alemães no sul do Brasil. Canoas: Ulbra, 2004.
} 
em 1915, a comunidade germânica contribuiu com tantas empresas quanto aquelas de nome português.

Ocorreu, rapidamente, um estreitamento de laços, pois, como já referido, o governo alemão, no final do século XIX, buscou estimular o comércio entre as empresas de seu país com as regiões para onde haviam migrado populações germânicas $^{48}$. A Alemanha era a segunda maior importadora de produtos do Brasil, somente atrás dos Estados Unidos. No ano de 1913, quase 25\% das exportações do Rio Grande do Sul foram destinados à Alemanha ${ }^{49}$. Quando a guerra foi deflagrada, em 1914, a união das companhias de navegação alemãs estava resolvida a reduzir tarifas de transporte para as mercadorias enviadas com destino a Pelotas e Porto Alegre ${ }^{50}$.

A guerra frustrou a continuidade dessas transações, pois o eficiente bloqueio naval posto em prática pelos britânicos fechou as portas do mercado para a Alemanha. Nem informações podiam ser trocadas entre um lado e outro do Atlântico, uma vez que os cabos submarinos alemães ${ }^{51}$ haviam sido cortados, ainda no início das hostilidades. O quadro produziu a seguinte declaração de Borges de Medeiros, em sua mensagem anual:

Em 1915 a diminuição da importação só na alfândega desta capital fez baixar a renda aduaneira de $53 \%$, o que levou o digno inspetor a explicar o fato pela cessação da importação de origem alemã que, se não era a única neste estado, devido à germanização de seu comércio preponderava de modo incontestável, regulando mais do dobro das importações francesas e inglesas ${ }^{52}$.

A economia gaúcha sentiu o impacto do conflito. As exportações do Rio Grande do Sul caíram quase 40\% de 1913 para 1914. Mediante as dificuldades impostas, as que eram feitas para outros países desceram vertiginosamente. Observe a tabela a seguir.

\footnotetext{
${ }^{47}$ LOVE, Joseph. O Rio Grande do Sul como fator de instabilidade na República Velha. In: FAUSTO, Boris (dir.). História Geral da Civilização Brasileira: estrutura de poder e economia (1889-1930). 8a ed., Rio de Janeiro: Bertrand Brasil, 2006.

${ }^{48}$ MAURO, op. cit.

${ }^{49}$ Mensagem do Presidente do Estado do Rio Grande do Sul à Assembleia dos Representantes, 1917, p. 54. Arquivo Histórico do Rio Grande do Sul.

${ }^{50}$ O Diário. Porto Alegre, 7 de julho de 1914.

${ }^{51}$ Primeiro o cabo que ligava Emden a Nova lorque, nas proximidades dos Açores; em seguida, o cabo que ia de Borkum a Pernambuco, passando por Tenerife e Monrovia. A FEDERAÇÃO. Porto Alegre, 12/06/1915.

${ }^{52}$ Mensagem do Presidente do Estado do Rio Grande do Sul à Assembleia dos Representantes, 1917, p. 53. Arquivo Histórico do Rio Grande do Sul.
} 
COMÉRCIO DO ESTADO COM PAÍSES ESTRANGEIROS ${ }^{53}$

\begin{tabular}{|c|c|c|c|}
\hline & EXPORTAÇÃO & IMPORTAÇÃO & TOTAL \\
\hline 1906 & 23.529:969 & $35.655: 322$ & 59.185:291 \\
\hline 1907 & 22.294:977 & 48.727:766 & 71.022:693 \\
\hline 1908 & 15.823:595 & 49.214:647 & 65.038:242 \\
\hline 1909 & 23.094:440 & $50.171: 746$ & 73.266:186 \\
\hline 1910 & 19.905:186 & $57.697: 772$ & 77.602:958 \\
\hline 1911 & $21.630: 337$ & 65.709:498 & 87.339:958 \\
\hline 1912 & 21.925:516 & 75.314:573 & 97.240:089 \\
\hline 1913 & 20.950:073 & $83.812: 924$ & 104.762:997 \\
\hline 1914 & 13.147:940 & $49.298: 240$ & 62.448:180 \\
\hline 1915 & $15.805: 000$ & 42.377:000 & 58.152:000 \\
\hline
\end{tabular}

Em seguida houve uma pequena e gradual recuperação. Mesmo com a demanda criada para alguns produtos que ajudaram para que as exportações permanecessem ativas, o valor obtido permaneceu inferior. Em 1915, o valor total das exportações permanecia abaixo do início da década ${ }^{54}$.

As importações, que até então vinham em ritmo acelerado tiveram queda brusca. De 1913 para 1914, caíra quase 50\%. Em 1915, se repetiu a tendência, marcada por nova queda ${ }^{55}$. Somente na alfândega de Porto Alegre, no ano de 1915 , as rendas aduaneiras haviam caído 53\%. Impacto que mostra a superioridade das relações entre o comércio da capital com a Alemanha. Sem dúvida, tal presença não era a única existente na cidade, todavia determinante, uma vez que era superior ao dobro das importações feitas junto à França e à Inglaterra em conjunto ${ }^{56}$.

Para o governo, a perda de arrecadação foi o pior efeito, já que o imposto de importação era uma importante fonte de receita. A receita obtida com exportação se tornara cada vez menor porque o governo continuamente abrira mão desse valor com o objetivo de estimular a produção, com vias a fazer o estado alcançar a autossuficiência em relação ao abastecimento interno. Como decorrência da situação,

\footnotetext{
${ }^{53}$ Relatório da Secretaria do Interior e Exterior ao Presidente do Estado do Rio Grande do Sul, 1916, p. 361. Arquivo Histórico do Rio Grande do Sul.

${ }^{54}$ Mensagem do Presidente do Estado do Rio Grande do Sul à Assembleia dos Representantes, 1917, p. 54. Arquivo Histórico do Rio Grande do Sul.

${ }^{55}$ Relatório da Secretaria do Interior e Exterior ao Presidente do Estado do Rio Grande do Sul, 1916, p. 361. Arquivo Histórico do Rio Grande do Sul.

${ }^{56}$ Mensagem do Presidente do Estado do Rio Grande do Sul à Assembleia dos Representantes, 1917, p. 53. Arquivo Histórico do Rio Grande do Sul.
} 
maior ficou a dependência em relação aos tributos territoriais; os impostos sobre a posse e sobre a transmissão da terra ${ }^{57}$.

Embora muitas das empresas citadas nas listas negras tivessem vínculos mais estreitos com o setor de exportação, o que relativizava um pouco a importância delas como contribuintes, a administração do governo Borges de Medeiros se esmerou em atender aos clamores dos listados, fato que pode ser comprovado pela farta comunicação entre o presidente do estado e o Ministério das Relações Exteriores brasileiro. Nelas, Borges de Medeiros solicitava que o Ministro intercedesse a favor das firmas, afiançando o caráter brasileiro, bem como a importância das mesmas para a economia. O esforço nesse sentido não deixou de ser visto com estranheza pela oposição que, através de seus periódicos, em diversos momentos, tentou tachá-lo de germanófilo e de aliado do Kaiser. Deve ser tomado em consideração que, os impostos territoriais insidiam com grande impacto nos grandes proprietários da região da Campanha gaúcha, que era base da oposição ao governo. Os latifundiários não tinham motivos para ver com condescendência o empenho do governo estadual em livrar uma parcela do setor produtivo, que era beneficiada com isenções, enquanto eles permaneciam onerados.

Contribuíam para as insinuações contra o governo gaúcho as boas relações cultivadas pelo governo do PRR como exército nacional, fato que favorecia o epíteto de militarista atribuído ao partido no poder. De igual maneira, a Alemanha cultivava grande apreço pela casta militar, de onde saía parte da elite política do Reich, o que propiciava comentários jocosos e comparações indiscretas entre o Rio Grande do Sul e a Alemanha. Em alguns círculos sociais críticos ao governo gaúcho ambos governos eram vistos como complementares ${ }^{58}$.

Em verdade, o republicanismo manteve uma postura cautelosa em relação aos imigrantes de origem alemã no Rio Grande do Sul. Continuando a política já estabelecida pelo líder precursor do partido (Júlio de Castilhos), Borges mesclou a pressão direta com tentativas de cooptação ${ }^{59}$. Em determinados momentos, além de não se furtar a fazer elogios às importantes contribuições feitas por indivíduos dessa etnia no estado, também introduziu no partido alguns indivíduos que mais tarde se tornaram importantes na nominata republicana, como foram os casos de Alberto Bins, Arno Philipp e Jakob Kroeff (tanto o Filho quanto o Netto).

\footnotetext{
${ }^{57}$ ALMEIDA, Pedro; CARVALHO, Maria Lúcia; PEREIRA, Paulo Roberto. Incentivo fiscal às exportações gaúchas durante a Primeira República. Ensaios FEE, Porto Alegre, v. 19, n. 1, p. 254-301, 1998.

${ }^{58}$ É o caso da revista humorística $O$ Maneca. O semanário publicado em Porto Alegre fazia constantes alusões à afinidade política entre os governantes da Alemanha e do Rio Grande do Sul.

${ }^{59}$ GERTZ, René. O castilhismo e a colônia alemã. In: AXT, Gunter (org.). et al. Júlio de Castilhos e o paradoxo republicano. 1a ed., Porto Alegre: Nova Prova, 2005.
} 
Os desdobramentos da guerra, ao provocarem repercussões em solo brasileiro, facultaram a submissão da comunidade residente em Porto Alegre ante a autoridade governamental. A Liga das Sociedades Germânicas, por ocasião do caso do Hotel Schmidt, enviou correspondência a Borges de Medeiros manifestando total confiança na sabedoria e benevolência do governo. Também afirmava que o proprietário do hotel infelizmente era alemão, mas que não possuía nenhuma ligação com qualquer entidade germânica, assim lavando as mãos em relação ao réu ${ }^{60}$.

O fato foi registrado e condenado pelo militante anarquista Friedrich Kniestedt ${ }^{61}$. Opositor declarado de qualquer ideal nacionalista, ele mostrou indignação diante do abandono sofrido pelo hoteleiro entregue à própria sorte. Segundo Kniestedt, muitos alemães e descendentes que cantavam as bravatas guerreiras, próprias do sangue germânico, se apreçaram em manifestar sua brasilidade e a condenar publicamente o hoteleiro como um pária.

Deve ser recordado que no período entre 1915 e 1917, houve várias atribulações. Borges teve de lidar com uma crise interna no partido, com o afastamento de republicanos históricos, no episódio do lançamento da candidatura de Hermes da Fonseca como senador pelo Rio Grande do Sul, de acordo com a indicação de Pinheiro Machado. Houve o assassinato do próprio Pinheiro Machado. Além da doença que afastou Borges do governo por cerca de um ano e a posterior reeleição do mesmo ao governo. Por certo, o período foi propício a ataques por parte dos inimigos políticos.

De todo modo, a etnia germânica era importante para a pluralidade produtiva do estado, o que ia ao encontro do pensamento positivista que norteava o governo, uma vez que a variedade fazia com que se alcançasse a tão almejada autossuficiência produtiva. Além do mais, a comunidade germânica representava uma ameaça efetiva muito menor do que a oposição política da região da Campanha e a dos dissidentes do $\mathrm{PRR}^{62}$.

Não obstante, também é preciso lembrar que, na segunda metade da década de 1910, a inflação teve uma significativa elevação. Com a queda das transações internacionais e a consequente fuga de capital, o governo brasileiro apelara para a emissão monetária. Problema esse que deve ser agregado ao crescimento da demanda externa por gêneros de primeira necessidade, em virtude da guerra, o que provocou uma evasão da produção gaúcha. Ambos fatores foram responsáveis pelo

${ }^{60}$ GOVERNO DO RIO GRANDE DO SUL ao Ministério das Relações Exteriores, 25 de abirl de 1917. Contabilidade/Rio Grande do Sul, 1910-1926. Maço: 310/3/12 - Arquivo Histórico do Itamaraty.

${ }^{61}$ GERTZ, René (ed.). Memórias de um imigrante anarquista (Friedrich Kniestedt). 1a ed., Porto Alegre: EST, 1989.

62 KOTHE, Mercedes Gassen. Os descendentes alemães. In: BOEIRA, Nelson; GOLIN, Tau. (coords.). República Velha (1889-1930). 1a ed., Passo Fundo: Méritos, 2007. 
encarecimento do custo de vida e que gerou manifestações populares. Uma vez que o comércio de exportação estava, predominantemente, nas mãos de uma maioria de nome alemão, foi recorrente, nos protestos realizados pela classe trabalhadora, a associação com este grupo étnico do termo "açambarcador". Dava-se forma a um bode expiatório conveniente. A expressão "açambarcador" foi recorrente durante o movimento grevista deflagrado em 1917, na capital ${ }^{63}$. Quando se falava das dificuldades enfrentadas com a carestia do custo de vida, esses senhores de nomes difíceis eram lembrados de maneira pouco recomendável.

Um comportamento nesse sentido possuía caráter contraditório na medida em que permitia que uma questão étnica se sobrepusesse à questão econômica, enquanto instrumento de análise, mas estrategicamente era justificável. Os meses que antecederam a eclosão da greve foram marcados por manifestações patrióticas e de negação a toda a forma de expressão cultural germânica, o que "impediu o movimento operário de exibir publicamente seu descontentamento ou regozijo: de 6 de abril a 31 de julho não há registro de qualquer greve ou manifestação" ${ }^{64}$. O turbilhão de eventos pelo qual o ano de 1917 atravessou não possibilitou que o movimento operário, através de suas lideranças e pelas manifestações de massa, expressasse livremente os seus argumentos. Uma vez que a comunidade germânica encontrava-se sob suspeição - lembrando que em abril muitas empresas haviam sido depredadas - talvez o comportamento das lideranças tivesse tido o objetivo de granjear simpatia para as reivindicações operárias junto à opinião pública e marcar uma posição de distinção. É bom lembrar que a etnia germânica teve papel fundamental na formação do movimento operário no Rio Grande do Sul e na cidade de Porto Alegre ${ }^{65}$ e, agindo assim, poderiam estar tentando evitar futuros dissabores. Por outro lado, a perda de poder aquisitivo entre a classe trabalhadora acabou favorecendo o estabelecimento de uma atmosfera favorável à divulgação das listas negras, por menor que fosse a sua legitimidade de direito - até novembro de 1917.

Mesmo que o movimento operário estivesse permeado pelo ideário anticapitalista, é possível que tenha persistido um certo oportunismo ou simples

\footnotetext{
${ }^{63}$ SILVA JR., Adhemar Lourenço. A greve geral de 1917 em Porto Alegre. Anos 90: revista do programa de pósgraduação em História, Porto Alegre, no 5, p. 183-205, 1996.

64 Idem, p. 186.

65 MARÇAL, João Baptista. Primeiras lutas operárias no Rio Grande do Sul: origens do sindicalismo rio-grandense. 1a ed., Porto Alegre: Livraria do Globo 1985. PETERSEN, Silvia Regina Ferraz. "Que a união operária seja a nossa pátria!": História das lutas operárias gaúchas para construir suas organizações. 1a ed., Santa Maria: Editora UFSM; Porto Alegre: Ed. Da Universidade/UFRGS, 2001. As obras em questão evidenciam o papel precedente dos operários de etnia germânica na formação de um movimento reivindicatório. Merece destaque a obra de Isabel Bilhão que evidencia a maneira pela qual foi sendo constituída uma identidade proletária em meio a uma pluralidade étnica, dentre as quais a germânica possuía destaque. BILHÃO, Isabel. Identidade e trabalho: uma história do operariado porto-alegrense (1898-1920). 1a ed., Londrina: Eduel, 2008.
} 
estratégia de preservação. Por certo, havia uma carência de referenciais práticos a serem tomados como exemplares, uma vez que a Segunda Internacional havia sucumbido em virtude da traição perpetrada pelas principais lideranças dos partidos social-democratas, ao abandonarem os ideais pacifistas do Congresso da Basiléia (1912), apoiando a participação operária na Primeira Guerra. Ao que parece, o fato do Brasil ter sido um país marcado pela existência de diversas nacionalidades em contato, "as ideias de classe e nação enfrentavam-se e misturavam-se mutuamente" ${ }^{66}$.

No entanto, a repercussão do comportamento dos anarquistas foi significativa. O exemplo dado por eles está relacionado com a publicação do Manifesto Anarquista, de repúdio à guerra e aos interesses econômicos envolvidos. Sendo mais incisivos nas críticas e coerentes na oposição com relação à luta de classes, acabaram sendo castigados pela crítica. No texto anarquista todos os países envolvidos no conflito eram contestados.

\footnotetext{
Trabalhadores! Há muito que os aliados dizem que batem-se pela liberdade, pela justiça e pelo direito. Outro tanto dizem os austro-alemães.

E tu povo, que não conheces as intrigas diplomáticas, és capaz de concenciosamente dizer quem tem razão?

Não, porque não são os fins da guerra, porque se o fosse era justo o teu patriotismo, porque pátria, no seu sentido lato é patrimônio, patrimônio é propriedade $[\ldots]^{67}$.
}

Como resultado, espíritos mais sensíveis ficaram melindrados com a publicação, vendo nela uma mensagem cifrada de germanismo. Previsivelmente, foi levantada a existência de relação entre a etnia e o esforço de guerra do momento. 0 jornal $O$ Independente se levantou em oposição, ao passo em que denunciava aquilo que seria um embuste de alemães inescrupulosos. Contra os mesmos afirmara:

\footnotetext{
Não nos pode ser juízo que os signatários deste boletim subversivo sejam anarquistas residentes nesta capital, não passando, ao que julgamos, dalgum trabalhinho destes retovados teutos que vivem entre nós e que ocupam alguns, lugares de destaque e de representação.

[...] Os anarquistas residentes em Porto Alegre, entre os quais vivem cidadãos de respeitabilidade, deviam lançar seu protesto, pondo a mostra a máscara com que alemães e retovados querem se cobrir ${ }^{68}$.
}

\footnotetext{
${ }^{66}$ BIONDI, Luigi. Identidade de classe e identidade nacional entre solidariedade e conflito: socialistas e republicanos italianos na São Paulo do início do século XX e suas relações com as associações patrícias e o nascente sindicalismo. Estudos Ibero-americanos, Porto Alegre, v.26, n.1, p.131-162, 2000.

${ }^{67}$ Arquivo Histórico do Rio Grande do Sul. Maço 151.

${ }^{68}$ O INDEPENDENTE. Porto Alegre, 1/02/1918.
} 
Algumas conclusões podem ser depreendidas do que foi exposto. No contexto, o discurso se tornou menos relevante do que o sangue daqueles que o pronunciavam. Significou que, a situação se agravara devido ao fato de muitos dos operários que manifestavam convicções políticas anticapitalistas terem sido alemães de nascimento. Tal fato fomentava nos seus críticos a recorrente lembrança desta origem germânica, e estes a evocaram continuamente nas suas argumentações. Tais críticos afirmavam que os militantes do movimento operário, só por serem alemães questionavam os interesses de "todos" os países envolvidos na guerra; não propriamente pelas suas convicções, mas porque aquilo que, supostamente, pretendiam os militantes seria apenas ludibriar os brasileiros, para que estes se esquecessem dos verdadeiros vilões da guerra: eles próprios, os alemães. Isso criava um círculo vicioso. Logo, pode-se depreender que as manifestações políticas populares foram influenciadas pelo envolvimento do Brasil com a guerra, ficando atreladas à questão da identidade nacional. Ou seja, se o indivíduo concordasse com determinada conduta era brasileiro, se não concordasse era antibrasileiro; ou pior, era alemão! Em algumas situações, os patrões eram tidos como alemães por contribuírem para a carestia do povo, em outras, os trabalhadores eram considerados alemães por fazerem greves ou por contestarem alguns dos objetivos da guerra.

Mais uma vez, foram os anarquistas que buscaram deixar marcada uma separação entre classe e nacionalidade. De acordo com as memórias de Kniestedt, alguns dos sindicatos de Porto Alegre junto à Federação Operária do Rio Grande do Sul (FORGS) haviam cogitado a construção de um tiro de guerra para a instrução militar dos operários. O plano não teria dado certo em função da ação dos anarquistas da Liga Operária $^{69}$.

O comportamento peculiar do líder socialista Carlos Cavaco é exemplar dessa contradição de identidades. A sua conduta deve ter resultado mais do seu ímpeto de paladino do que propriamente de alguma convicção ideológica, uma vez que ele não poderia ser considerado propriamente um proletário, nem um conhecedor das concepções socialistas, tendo uma formação pessoal suis generis ${ }^{70}$. A sua posição com relação à guerra mudou de cética em 1914, quando ele a via apenas como um conflito que afligiria o operariado, para antigermânica em 1917. Cavaco arregimentou voluntários para formar os Legionários do Sul, que "desfilaram pelas ruas de Porto

\footnotetext{
${ }^{69}$ GERTZ, op. cit.

${ }^{70}$ Contudo, o próprio socialismo em Porto Alegre apresentava-se nebuloso e não poderia ser considerado um equivalente do movimento da Alemanha. SCHMIDT, Benito Bisso. O patriarca e o tribuno: caminhos, encruzilhadas, viagens e pontes de dois líderes socialistas - Francisco Xavier da Costa (187?-1934) e Carlos Cavaco (1978-1961). Campinas: Unicamp, 2002. Tese (Doutorado), Faculdade de História, Universidade de Campinas, 2002.
} 
Alegre, usando uma faixa verde e amarela e entoando hinos patrióticos [e] fomentaram o clima belicoso existente na cidade" ${ }^{71}$. A sua posição pessoal de virulenta repulsa à Alemanha e à cultura vinculada a esta terra teve efeito em parte do operariado da cidade.

Importante para a difusão desse sentimento de repulsa foi o medo relacionado ao "perigo alemão". Essa ideia partia da crença difundida no Brasil de que os imigrantes e descendentes se mantiveram propositalmente não integrados à sociedade brasileira e que os mesmos eram parte da estratégia alemã de explorar outros países de modo dissimulado ${ }^{72}$. Desde o surgimento do Estado alemão, com a anexação da Alsácia-Lorena à custa da França, havia essa paranóia, mas a Lei de Emigração alemã, de 1897, estimulou-a. A lei previa que somente sairiam do país aqueles que embarcassem em navios alemães, desde que o destino não fosse para estados com entrada subsidiada (principalmente São Paulo), além disto, dava apoio à vinda para o Brasil, no caso das pessoas irem para os três estados do sul ${ }^{73}$. Como resultado, se argumentava que no sul do país os quistos étnicos facilitariam uma futura anexação. Assim, a retórica do perigo alemão se manteve viva durante boa parte do período republicano porque, como se não bastasse, perpetuava-se a crença de que havia um caráter monarquista entre os imigrantes germânicos. O receio cresceu em intensidade durante a Primeira Guerra, embora desconsiderasse as causas internas, elementares para explicar a dificuldade de inserção do imigrante na sociedade brasileira.

Naquela conjuntura, portanto, as arbitrariedades encontraram terreno fértil para serem praticadas, apesar de terem, explicitamente, sido reprovadas e combatidas pela autoridade constituída. Nesse momento, é preciso reconhecer a importância dos periódicos da cidade de Porto Alegre. Embora o jornal oficial do governo e do Partido Republicano Riograndense, $A$ Federação, mantivesse um tom conciliador, com vistas a serenar os ânimos populares e desmistificar boatos que surgiam, inclusive após a ruptura de relações entre os países, outros órgãos ${ }^{74}$ aproveitaram-se da situação para levantar dúvidas sobre indivíduos, empresas, associações e sobre a etnia germânica como um todo. A ameaça, sob forma de vigília pela honra brasileira foi um recurso de algumas redações, apesar de, até o presente momento, não haver nenhuma

\footnotetext{
${ }^{71}$ Idem, p. 495.

72 GERTZ, op. cit.

${ }^{73}$ KOTHE, op. cit.

${ }^{74} \mathrm{O}$ caso do jornal $O$ Independente é exemplar. Até 1917 manteve uma postura neutra exemplar, mas neste ano começou uma campanha de oposição à cultura germânica em geral e denunciava a existência de inimigos em muitos lugares da cidade.
} 
informação embasada que permita afirmar o envolvimento de qualquer habitante da cidade com a causa alemã no período posterior à ruptura de relações entre os países.

Por certo, fazendo um breve apanhado, é possível confirmar quatro indicativos relacionados à situação. Em primeiro lugar, havia uma grande comunidade germânica, formada por alemães e teuto-brasileiros. Em segundo lugar, dessa comunidade saíram nomes representativos do movimento operário, bem como os nomes mais expressivos da indústria e do comércio da capital e do estado. Em terceiro, por interesses econômicos, essa comunidade aproximou-se continuamente da Alemanha desde o começo do período republicano. Por fim, entre todos os países existentes, a Alemanha era o principal parceiro comercial do Rio Grande do Sul e, no Brasil, superava a GrãBretanha em alguns quesitos. Na medida em que as outras potências se aliaram contra a Alemanha, em virtude da guerra, o objetivo era destruir as ligações desta com a América, inclusive com o Brasil.

Essas constatações foram também feitas pelos franceses durante o andamento da guerra. Desde o início dela, o governo francês sondou empresários gaúchos sobre a possibilidade de importar gado cavalar e muar para o esforço de guerra. Em 1915, um certo senhor E. Nicot de Villemain entregava a Borges de Medeiros um estudo sobre as condições econômicas gaúchas, destacando o absoluto predomínio alemão sobre as exportações do estado até a guerra ${ }^{75}$. Mostrava que, por causa disso, o bloqueio de Hamburgo causou um transtorno à economia regional. Como a presença francesa havia sido muito diminuta até então, o senhor Villemain apontava o quão vantajosa poderia ser uma aproximação entre ambos países. No ano seguinte, o governo francês comunicava ao Ministério das Relações Exteriores do Brasil o desejo de criar uma legação diplomática em Porto Alegre, objetivando "fomentar o desenvolvimento das relações econômico-comerciais" ${ }^{76}$ com o Rio Grande do Sul. Em 1917, um representante do governo francês, o médico Georges Dumas - a quem se atribui a responsabilidade da ideia que veio a dar origem à missão médica brasileira que partiu para o front ${ }^{77}$-, trouxe consigo uma série de presentes para Borges de Medeiros, com quem esteve em reunião e tendo para o mesmo solicitado a subscrição, junto às cidades gaúchas, de um empréstimo de auxílio ao esforço de guerra. No ano seguinte, as medidas necessárias eram agilizadas pela legação brasileira em Paris, junto ao Ministério dos Negócios Estrangeiros da França, para a realização de negócios entre a

\footnotetext{
${ }^{75}$ A FEDERAÇÃO. Porto Alegre, 27/04/1915.

76 MINISTÉRIO DAS RELAÇÕES EXTERIORES, ao governo do Rio Grande do Sul, 5 de maio de 1916. Contabilidade/Rio Grande do Sul, 1901-1917. Maço: 310/3/8 - Arquivo Histórico do Itamaraty.

${ }^{77}$ KROEFF, Mario. Imagens do meu Rio Grande. 1a ed., Rio de Janeiro: Impressora Brasileira, 1971.
} 
intendência de Porto Alegre e a empresa Société Gramme, para a geração de eletricidade ${ }^{78}$.

Por sua vez, os Estados Unidos mostravam preocupação com o futuro das suas relações com o Brasil, que estavam cada vez mais sólidas. A importância alcançada pelas relações comerciais entre ambos países justificava o temor com relação a possíveis alterações. Isso justifica a apreensão norte-americana com alguns boatos, entre os quais, um que afirmava que cidadãos de Porto Alegre estariam envolvidos com a criação de uma sociedade secreta com fins de estabelecer a supremacia alemã no sul do país, com o uso de clubes de tiro financiados pela Alemanha, segundo aponta uma correspondência enviada pela sua embaixada em documento confidencial ${ }^{79}$. Outrossim, impuseram ao Brasil, em 1917, a sua própria versão da Statutory List, chamada de American Enemy-Trading List, fiscalizada pelos cônsules espalhados em território brasileiro. Inicialmente, foi uma cópia da lista britânica, mas com o tempo adquiriu características próprias. Estavam passíveis de inclusão quaisquer empresas que negociassem, com súditos inimigos ou aliados dos inimigos, alguma mercadoria produzida nos EUA, que contivesse, agregada a si, qualquer produto norte-americano, ou que fosse montada nos EUA, independente da origem das matérias-primas. Assim como a britânica, a norte-americana arrolou várias empresas no Rio grande do Sul. No mesmo ano começaram os preparativos para instalar companhias frigoríficas - Armour e Swift - no estado, motivadas pela necessidade dos países aliados, ainda envolvidos na conflagração mundial ${ }^{80}$.

Segundo a Gazeta Colonial ${ }^{81}$ (antes da proibição do uso do idioma alemão era conhecida como Neue Deutsche Zeitung, e que manifestou inconformidade naquilo que tange ao tratamento destinado aos alemães radicados no país e aos teutobrasileiros), os norte-americanos haviam formulado uma Lista Branca das empresas com as quais seria totalmente lícito negociar. O consulado deles, no Rio Grande do Sul, se encontrava na cidade de Rio Grande, mas para melhor aplicabilidade da lista, transferiu, em 1918, a sede para a capital do estado.

Nesse mesmo ano, era possível encontrar, nas listas britânica e norteamericana, inúmeros estabelecimentos arrolados como suspeitos de relações com o inimigo. A Gazeta Colonial - que também estava listada - publicou o rol dos acusados

\footnotetext{
${ }^{78}$ MINISTÉRIO DAS RELAÇÕES EXTERIORES, ao Presidente do Estado do Rio Grande do Sul, 31 de outubro de 1918. Contabilidade/Rio Grande do Sul, 1918-1926. Maço: 310/3/9 - Arquivo Histórico do Itamaraty.

${ }^{79}$ MINISTÉRIO DAS RELAÇÕES EXTERIORES, ao Vice-Presidente em exercício do Estado do Rio Grande do Sul, ? de julho de 1916. Contabilidade/Rio Grande do Sul, 1901-1917. Maço: 310/3/9 - Arquivo Histórico do Itamaraty.

${ }^{80}$ LOVE, op. cit.

${ }^{81}$ GAZETA COLONIAL. Porto Alegre, 8/05/1918.
} 
como transgressores ${ }^{82}$. Aparecem cinquenta e sete nomes apontados pela lista inglesa, enquanto são trinta e oito os nomes apontados pela lista norte-americana, dos quais trinta e dois se repetem em ambas. O caráter germânico expresso por elas é constatado pelo fato de vinte e três nomes (de pessoas físicas e de empresas) serem alemães, embora de fato, o número seja maior porque algumas empresas com nomes em português, contavam com proprietários cujos nomes eram sabidamente alemães. Dentre os nomes, alguns possuíam relações entre si, como se pode ver no caso da empresa Bromberg, que mantinha relações estreitas com outras empresas vigiadas, como foi o caso da Ao Cylindro, que distribuía os produtos Bromberg pelo interior do estado. Outro nome era a da Companhia Graphica Riograndense, proprietária do jornal O Diário, que havia sido empastelado em abril de 1917, pelo seu comportamento germanófilo.

No impulso das listas surgidas, os alemães e teuto-brasileiros passaram a ter de se preocupar com a impertinência de grupos nativistas. A Liga de Resistência Nacional $^{83}$, criada em Porto Alegre em outubro de 1918, se propunha, além de nacionalizar todos os nomes existentes em língua estrangeira, a publicar uma própria Lista Negra de casas alemãs que os brasileiros deveriam evitar, no interesse de combater o inimigo ${ }^{84}$.

Apesar das imensas dificuldades sofridas com a ação da fiscalização, as empresas sobreviveram no período pós-guerra. Um dos fatores contribuintes foi a contínua ligação entre as famílias através de casamentos. Esse nível de inter-relação foi essencial para a sobrevivência dos negócios. Ocorria um aprofundamento das relações no interior da etnia, mediante o estabelecimento de laços matrimoniais e de associações comerciais, que se prestavam à concentração de capital, mas, como efeito colateral na sociedade, servia para despertar desconfianças quanto às qualidades morais dessa gente.

Se, como afirma Jean Roche ${ }^{85}$, as cicatrizes no âmago dos indivíduos custaram a passar, o mesmo não pode ser dito sobre a economia vinculada a eles. Em 1920, no Rio Grande do Sul, havia decrescido, em cerca 2/3, o número de fábricas, em relação ao início da década anterior, mas, em compensação, o capital delas quase dobrou, no mesmo período. A queda foi normal dentro do contexto nacional, pois o estado manteve sua posição entre os mais desenvolvidos do país. Dez anos após o início da

\footnotetext{
82 GAZETA COLONIAL. Porto Alegre, 4/05/1918.

${ }^{83}$ Não confundir com a Liga de Defesa Nacional. Entre suas manifestações pode-se encontrar a tentativa de mudar os nomes dos logradouros públicos estrangeiros para o vernáculo. Ver: Correspondência Geral Expedida. Intendência de Porto Alegre, 30 de dezembro de 1918 - Arquivo Histórico Moysés Vellinho.

${ }^{84}$ ROCHE, op. cit., p. 716.

${ }^{85}$ Idem.
} 
Grande Guerra e cem anos após a chegada dos primeiros imigrantes germânicos, o número de empreendimentos desta etnia crescia sem sobressaltos, e eram majoritários no estado.

As casas comerciais também resistiram. Pelo que consta, a sua mobilização ${ }^{86}$ ajudou a desbancar as casas de origem francesa e inglesa que se insinuaram, e, em 1925, o comércio com a Alemanha alcançava o mesmo índice de 1913.

Portanto, possivelmente tenha parecido aos contemporâneos desses acontecimentos que os infames alemães não tinham aprendido a lição. Logo, restaria aos bravos brasileiros a missão de colocá-los no seu lugar mais uma vez, no momento em que a ocasião se apresentasse. Nessa perspectiva, talvez a década de 1940 tenha também servido para dar vazão a sentimentos que estivessem sendo represados há mais tempo.

${ }^{86}$ Idem. 